\title{
Two invasive species, Phenacoccus madeirensis Green and Phenacoccus solani Ferris (Hemiptera, Pseudococcidae) in Egypt
}

\author{
Rawda M. Badawy ${ }^{1 *}$, Maha I. Abd El Razzik², Sahar A. Attia ${ }^{2}$ and Omima A. Palpool ${ }^{2}$ \\ ${ }^{1}$ Entomology Department, Faculty of science, Ain Shams University, Cairo, Egypt \\ ${ }^{2}$ Plant Protection Research Institution, Agricultural Research Center, Dokki, Giza, Egypt
}

\section{A R T I C L E I N F O}

Article history:

Received 15 June 2016

Accepted 21 November 2016

Keywords:

Pseudococcidae;

Madeiran mealybug;

Solanum mealybug;

Mealy bugs;

Egypt.

\begin{abstract}
A B S T R A C T
Two alien Phenacoccus species are recorded in Egypt for the first time from two ornamental plants: Lantana camara (Verberaceae) and Leucoenia leucocephata (Fabaceae). The first invasive species is Phenacoccus madeirensis Green; while the second parthenogenetic species is Phenacoccus solani Ferris were collected during weekly visitation to the ornamental garden of Ministry of agriculture at Giza governorate. So these two species are added to the five Phenacoccus species of Egypt: Phenacoccus solenopsis Tinsley, Phenacoccus parvus Morrison, Phenacoccus halli Ezzat, Phenacoccus pyramidensis Ezzat and Phenacoccus gypsophilae Hall. Diagnostic characters, illustrations and photographic pictures for these two first recorded species are introduced.
\end{abstract}

\section{Introduction}

The increase of the world import and trade of several plant species facilitate the fast spread of many alien species. Scale insects are the highly invasive species due to their small size and their crawl activity. Detection of the mealy bugs on plants moving at agriculture quarantine are usually constitute a big problems due to the presence of the wax secretion and their occurrence mostly at the lower surfaces of leaves and sometimes on roots.

The entrance of the invasive species to the more favorable environmental condition without their natural enemies facilitate their dispersion and increase the possibility of causing economically significant damage and major risk to biodiversity. Mediterranean Basin is especially susceptible to insect invasions, due to climatic conditions being favorable for establishment of several species ${ }^{[1,2]}$.

Family Pseudococcidae (Hemiptera, Sternorrhyncha, Coccoidea,) includes the second most important soft scale insects after Coccidae. It has about 2689 world species in 263 genera and 313 Phenacoccus species. Palearctic region with the highest number of recorded species ${ }^{[2-4]}$. However there are highly numbers of mealy bug species restricted in the Mideterranean countries, but there are several species remain unrecorded in many parts of this geographical area ${ }^{[5]}$. This work reports the presence of these two recent invasive species of genus Phenacoccus.

* Corresponding author.

E-mail address: RawdaBadawi@ sci.asu.edu.eg

\section{Materials and methods}

Weekly visitations were carried out to a garden related to Ministry of Agriculture at Giza governorate from first May 2015 to the end of May 2016. The garden is cultivated with two commonly known ornamental plants: Lantana camara (Family Verbenaceae) and Leucoenia leucocephata (Family Fabaceae), in addition to some weeds and other shrubs. Collection was done from 10-12 AM, mainly concentrated at lower surfaces of leaves and also on the twigs of 20 infested plants. The examination of the collected specimens was done in the laboratory using binocular microscopic investigation. Slide mounted are made, colored photographs and illustrations for the most important characters were provided. Identification was carried out by using different keys ${ }^{[6-8]}$.

\section{Results and discussion}

Genus Phenacoccus (Cockerel, 1893); (Figs. 1-14)

Diagnostic characters: Oval soft bodied insects, dorsoventrally compressed; covered with cottony wax secretion, usually with lateral wax filaments. Female with 8-9 segmented antennae, 8-18 pairs of cerarii; usually with 2 or 3 cerculi, ventral lower cerculus with characteristic feature (Figs. 4 \& 14); legs well developed.

This genus was represented in Egypt by five species: Phenacoccus solenopsis Tinsley, Phenacoccus parvus Morrison, Phenacoccus halli Ezzat, Phenacoccus pyramidensis Ezzat and Phenacoccus gypsophilae Hall [6]. 
Phenacoccus madeirensis Green and Phenacoccus solani Ferris are added to the Egyptian phenacoccus species, during the present work.

\section{Phenacoccus madeirensis Green, 1923}

(Madeira mealy bug or Mexican mealy bug); (Figs. 1-10)

Phenacoccus madeirensis Green, 1923. Bulletin of Entomological Research 14: 90

\section{Diagnostic characters}

Female (Figs. 1-5) 2.5-3 $\mathrm{mm}$ in length, 0.9-1.45 $\mathrm{mm}$ in width, with dark reddish color. Body oval, covered with cottony secretion and has reddish honey dew (Figs. 1 \& 2), with 18 pairs of lateral wax filaments, the posterior pair is as long as body length (Fig. 5). Microscopically (Fig. 4): Antenna 9 segments; Circulus large centrally, oval with lateral process; hind tibia with 40 transculent pores; pentalocularand multilocular disc pores densely present with few discoidal pores; anal margin deeply emarginated and with concentrated oral tubular ducts; anal sclerite chitinized with 3 sharp spines in each half; anal cerarius with 3 sharp spines; dorsally with 18 pairs of Cerarii.

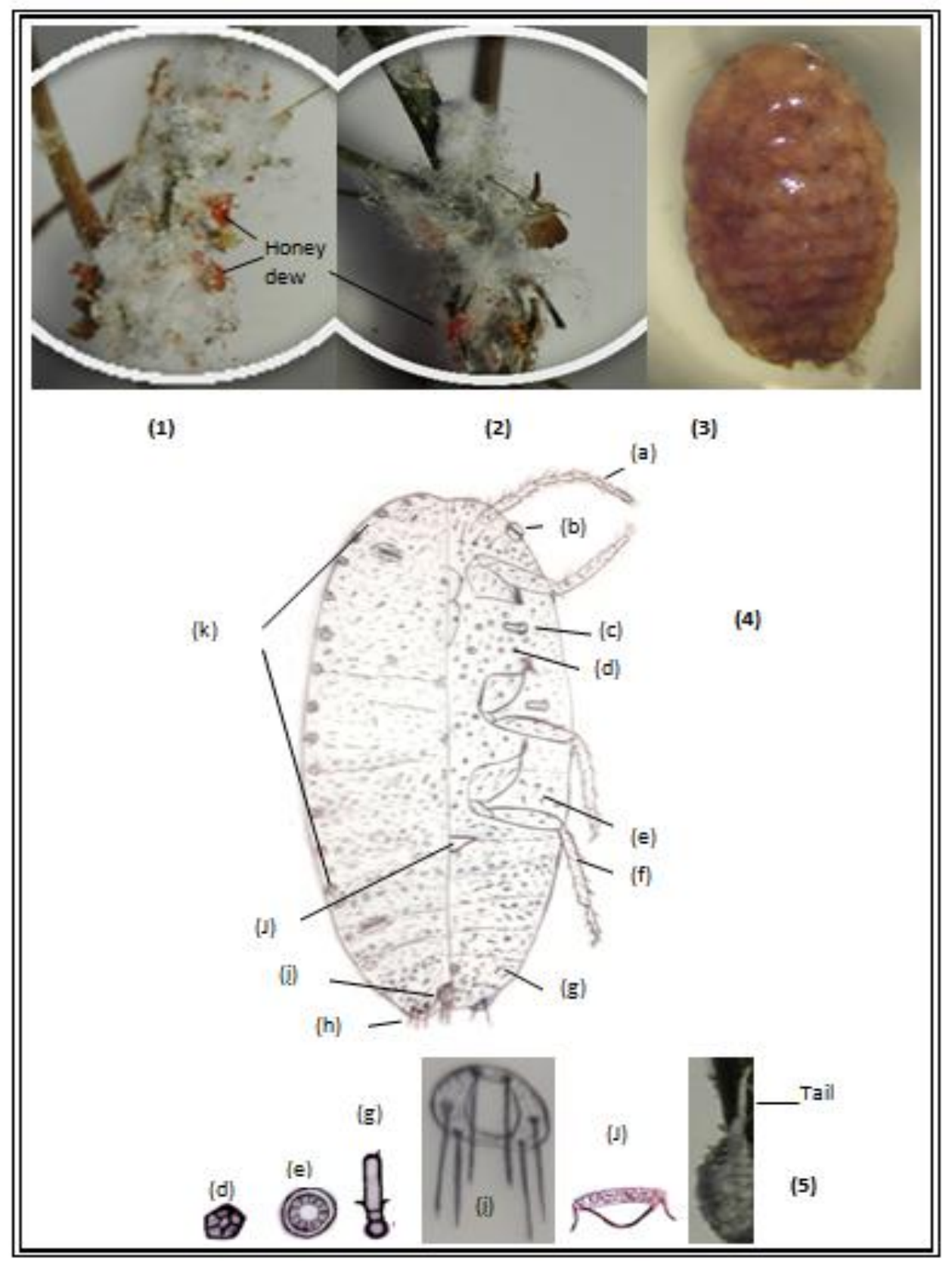

Figs (1-5): Phenacoccus madeirensis, female (1\&2): Field colony, (3): Adult female, (4): Female microscopically, (a): Antenna, (b): Eye, (c): Spiracle, (d): Pentalocular pore, (e): Multilocular pore (f): Hind leg, (g): Coller tubular duct, (h): Anal cerarius, (i): Anal sclerite, (J): Cerculus, (k) Dorsal cerarii; (5): Elongated posterior wax tail. 
Male (Figs. 6-10) large reddish, 2.5-3.5 $\mathrm{mm}$ in length; with triangular head, black bulged compound eyes, distance between eyes wider than the eye length, eye length equal 0.3 of head length. Thorax: Large triangular, legs slender elongated, hind leg equal the body length; wings transparent, with dense subcostal cross veins, 7 large branches apically, extended out of the abdomen by distance as length as the basal part. Abdomen with dark intersegmental patches and ends with two sharp curved elongated genital processes.

Geographical distribution: Originally described from Madeira (Portugal) and later from France, Italy, Spain, Greece, Turkey and other Palaearctic region; recently spread to Tropical Africa and Southern Asia.

\section{Remark}

Phenacoccus madeirensis Green is a first recent invader, collected from Leucoenia leucocephata (Fabaceae) and Lantana camara (Verbenaceae), appeared from July 2015 till September, then disappeared till $1^{\text {st }}$ May 2016. It is a polyphagus widespread species, recorded on 154 plant species especially ornamental and herbaceous plants, collected densely on ornamental Lead trees and white popinae, Leucoenia leucocephata (Fabaceae); this introduced species less rapidly spread around the Mideterranean countries ${ }^{[2,9]}$.

Elongated circulus and long posterior wax tail (as long as body length) easily differentiate $P$. madeirensis Green from closely related species $P$. halli Ezzat, which is characterized by circular circulus and relatively shorter posterior wax tail (less than body length).

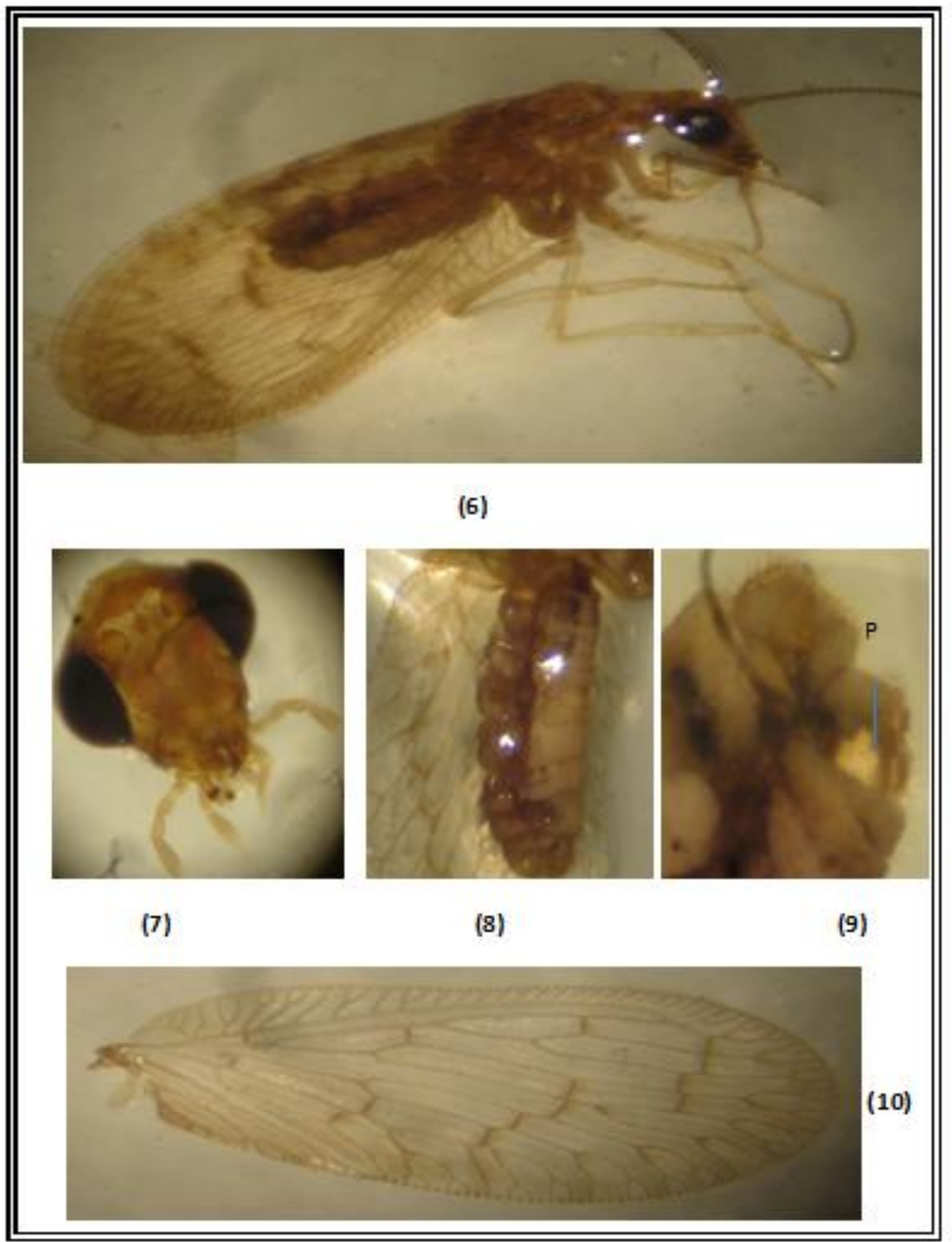

Figs (6-10): Phenacoccus madeirensis, male, (6): Laterally; (7): Head, (8): Abdomen; (9): Abdominal end, P: Two genital processes; $(\mathbf{1 0})$ : Fore wing. 
Phenacoccus solani Ferris, 1918

\section{(Solanum mealy bug); (Figs. 11\& 14)}

Phenacoccus solani Ferris, 1918: Standford Univ.Press, Palo Alto. California: 150 .

Phenacoccus Solani Ferris is parthenogenetic species, without male.

\section{Diagnostic characters}

Female small sized $(<1.7 \mathrm{~mm})$ in length slightly rounded, with dense whitish short wax secretion and honey dew, sometimes with few black dotes. Microscopically (Fig. 14): Female has 8-segmented antenna; without quinquelocular pores, with multilocular pores at segments 4 and 5 ventrally in a single row in median area; with 1-2 tubular ducts present near margins \& spiracles; with 20 translucent pores on hind tibia\& with small rounded circulus. Anal cerrii with two lanceolate setae and 3- 5 trilocular pores.

\section{Geographical distribution}

Italy, Spain, Turkey, Palastine, Iran, Korea and Australia.

\section{Remark:}

Phenacoccus Solani is the $2^{\text {nd }}$ recent invasive species, collected at $1^{\text {st }}$ May by large numbers on Lantana camara (Verbenacae). It has several host plants, but is common on Solanaceae, Crassulaceae and many ornamental plants ${ }^{[8,10]}$. Rapid spread of this species has a high impact to commercial tomato, sweet pepper and other vegetable crops specially that grown in glasshouses $[1,5]$

Phenacoccus solani Ferris can be distinguished from the closely species $P$. parvus Morrison by its whitish body color and 8-segmented antennae while the second species is dark yellow in color and 9-segmented antennae.

\section{Conclusion}

This paper reports the presence of Madeiran mealybug $P$. madeirensis Green and Solanum mealy bug, $P$. solani Ferris in Dokki, Giza and further investigations are needed to establish their current distribution in Egypt and possibilities of their domestication.

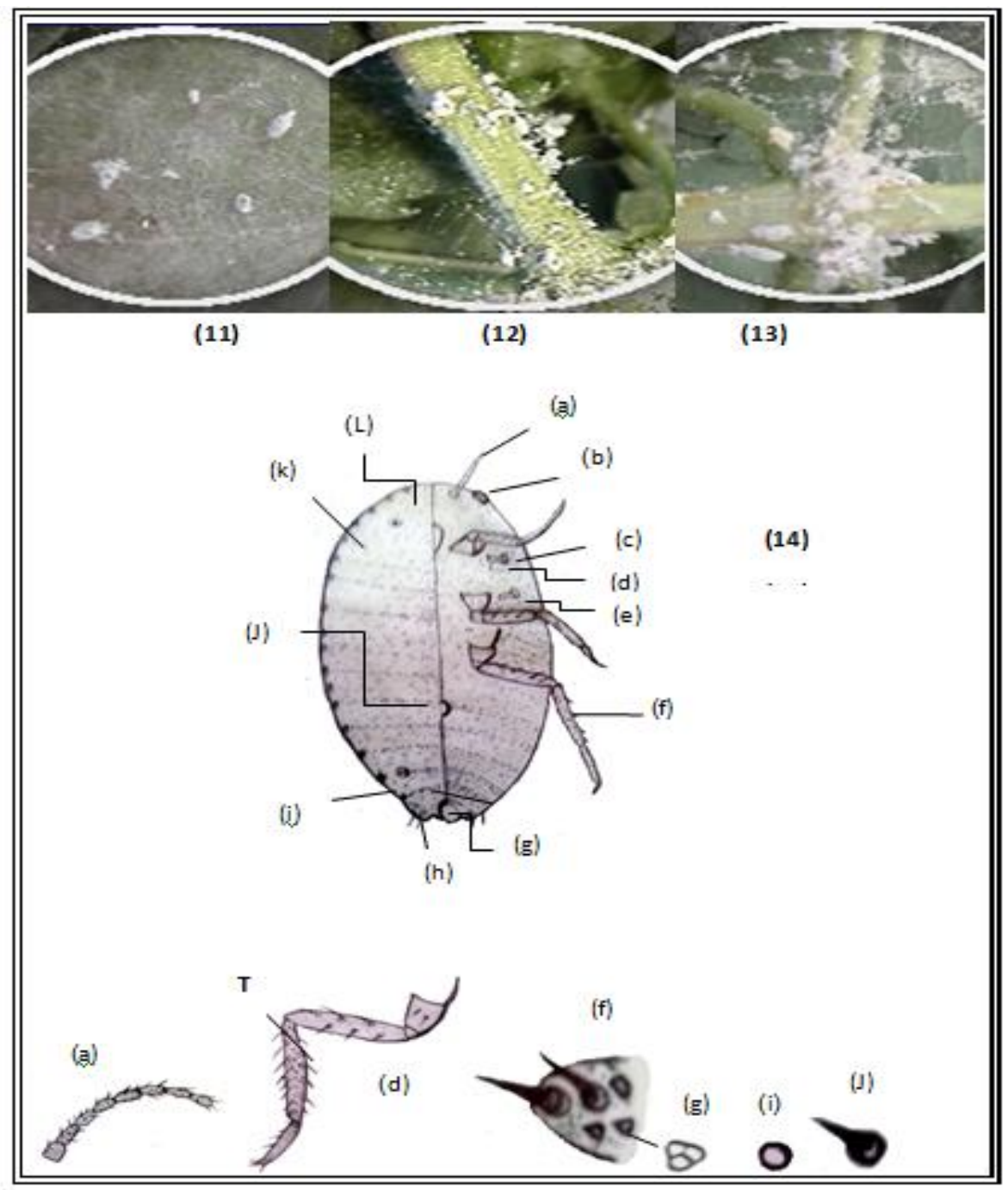

Figs. (11-14): Phenacoccus solani, female; (11-13): Fied colony; (14): Microscopically, (a): Antenna, (b): Eye, , (c): Spiracle, (d): Multilocular pore, (e): Tubular ducts, (f): Hind leg, T:Ttransculent pores, (g): Anal sclerite, (h): Anal cerarius, (i): Trilocular pore, $(\mathbf{J})$ : Cerculus, $(\mathbf{k})$ : Discoidal pore, $(\mathbf{L})$ : Dorsal seta. 


\section{References}

1) Pellizzari, G. and Porcelli, F. (2013). First record of Phenacoccus defectus in Italy, with comments on Phenacoccus solani and P.solenopsis. Bulletin of Insectology, 66(2):209-211.

2) Stathas, G. J., Kartsons, E. D. and Darras, A. I. (2015). Record of Phenacoccus peruvionus Granara de Willing and Phenacoccus madeirensis (Hemiptera: Pseudococcidae) on new host ornamental plants in Greece. Hellenic Plant Protection J., 8:12-14.

3) Abd-Rabou, S., Shalaby, H., Germain, J. F., Ris, N., Kreiter, P. and Malausa, T. (2012). Identification of mealybug pest species (Homoptera: Pseudococcidae) in Egypt and France, using a DNA bar-coding approach. Bulletin of Entomological Research, 109:1-9.

4) Moghaddan, M. (2015). New records of mealybug species in Iran with discussions on morphological variations (Hemiptera, Coccoidea: Pseudococcidae) Entomologica Fennica, 26:122-131.

5) Ben-Dov, Y. (2012). New data in the scale insects (Hemiptera: Coccoidea) of Tenelife, Canary Islands. Arquipelago-life and Larine science 30:71-74.
6) Abd-Rabou, S., Germain, J. F. and Malausa, T. (2010). Phenacoccus parvus Morrison et $P$. solenopsis Tinsly, duex co. chenilles nouvelles pour l'Egypte (Homoptera: Pseudococcidae). Bulletin de la societe Entomologigue de France, 115(4):509-510.

7) Mohammad, Z. K. and Moharum, F. A. (2012). Key to genera of Family Pseudococcidae in Egypt (Hemiptera: Coccoidea). Egypt. Acad. J. Biolog. sci., $5(3): 1-5$.

8) Kaydan, M. B., Erkilic, L. and Ulgenturk, S. (2012). An invasive mealybug species Phenacoccus madeirensis Green (Hemiptera: Coccoidea, Pseudococcidae) introduced recently into turkey. Turk. Entomol. Bull. 2(2):67-74.

9) Williams, D. J. and Hamon, A. B. (1994). Scientific note: Phenacoccus Parvus Morrison, a possible injurious mealy bug recorded for the first time from Florida (Homoptera: Coccoidea, Pseudococcidae). Insecta Mundi. Digital commons@university of Nebraska-Lincoln center for systematic Entomology, Gainesville Florida. http//digitalcommons unl.edu/insectamundi: 1-299.

10) Papadopoulou, S. and Chryssohoides, C. (2012). Phenacoccus madeirensis Green, 1923 (Homoptera: Pseudococcidae) on Ocimum basillicum: a new geographical record for Greece. EPPO Bull. 42(1): 146-147. 